\title{
Stress Corrosion Cracking of Austenitic Stainless Steels in Chloride Solutions*
}

\author{
By Takaaki Shimose**, Akira Takamura**, Kenji Mori** \\ and Kazutoshi Shimogôri**
}

\begin{abstract}
An investigation was carried out on the effects of the stress, chloride concentration, temperature and oxygen on the stress corrosion cracking behavior of 18-8 and 18-13 Mo steels. Tests were made in autoclaves with the chloride ion concentration of $0 \sim 300,000 \mathrm{ppm}$ at $130 \sim 250^{\circ} \mathrm{C}$. The susceptibility for stress corrosion cracking was found to increase with the increase of the chloride ion concentration and/or temperature. At temperatures below $150^{\circ} \mathrm{C}$, no stress corrosion cracking was observed except in a boiling $42 \% \mathrm{MgCl}_{2}$ solution. Above $180^{\circ} \mathrm{C}$, the susceptibility was much greater in the vapor phase than in the liquid phase. In air atmosphere the $18-8$ steel cracked at $180^{\circ} \mathrm{C}$ and at the $30,000 \mathrm{ppm}$ chloride ion concentration in the liquid phase and at $30 \mathrm{ppm}$ in the vapor phase, whereas at $250^{\circ} \mathrm{C}$ it cracked at $10 \mathrm{ppm}$ in the vapor phase. The addition of oxygen in autoclaves promoted the tendency to stress corrosion cracking; at $180^{\circ} \mathrm{C}$ the $18-8$ steel cracked at the $300 \mathrm{ppm}$ chloride ion concentration in the liquid phase and at $10 \mathrm{ppm}$ in the vapor phase. The 18-13 Mo steel was observed to be more susceptible than the 18-8 steel in the vapor phase and less susceptible in the liquid phase in a dilute chloride solution, whereas in the boiling $42 \% \mathrm{MgCl}_{2}$ solution both steels were almost equally susceptible. These results suggested the presence of difinite threshold stresses for the stress corrosion cracking which depended on the chemical compositions and corrosive environments such as temperature, and chloride and oxygen concentrations. It was also observed that in dilute chloride solutions all cracks originated in pits formed in both vapor and liquid phases and that a complete exclusion of oxygen eliminated the occurrence of stress corrosion cracking as well as pitting corrosion.
\end{abstract}

(Received September 18, 1964)

\section{Introduction}

Although numerous investigations have been reported on the transgranular stress corrosion cracking of austenitic stainless steels, the data on the factors affecting the stress corrosion cracking in the presence of a small amount of chloride at a high temperature are relatively few in number in spite of its practical importance. Fontana ${ }^{(1)}$ and Snowden ${ }^{(2)}$ studied the effect of corrosive environments on the stress corrosion cracking of 18-8 $\mathrm{Cb}$ steel, but the relationship between stress corrosion cracking and factors controlling the occurrence of crack- ing, such as chemical composition of material, stress, chloride concentration and temperature, remains unknown. In the present work the effects of the chloride concentration, temperature and oxygen on the stress corrosion cracking of the 18-8 steel and the 18-13 Mo steel were studied, and the apparent threshold stresses were obtained in some environments.

\section{Experimental Procedure}

\section{Materials}

Tables 1 and 2 show chemical compositions and me-

Table 1 Chemical compositions of materials.

\begin{tabular}{c|c|c|c|c|c|c|c|c|c}
\hline \hline Materials & $\mathrm{C}$ & $\mathrm{Si}$ & $\mathrm{Mn}$ & $\mathrm{P}$ & $\mathrm{S}$ & $\mathrm{Ni}$ & $\mathrm{Cr}$ & $\mathrm{Mo}$ \\
\hline 18_8 steel & 0.064 & 0.36 & 1.81 & 0.022 & 0.015 & 10.72 & 19.20 & - \\
18 13 Mo steel & 0.053 & 0.41 & 1.73 & 0.019 & 0.010 & 13.62 & 17.02 & 2.35 \\
\hline
\end{tabular}

Table 2 Mechanical properties of materials.

\begin{tabular}{|c|c|c|c|c|c|c|c|c|c|c|c|c|c|c|c|c|}
\hline \multirow{2}{*}{ Materials } & \multicolumn{4}{|c|}{$\begin{array}{c}0.2 \% \text { Yield strength } \\
\left(\mathrm{kg} / \mathrm{mm}^{2}\right)\end{array}$} & \multicolumn{4}{|c|}{$\begin{array}{c}\text { Tensile strength } \\
\left(\mathrm{kg} / \mathrm{mm}^{2}\right)\end{array}$} & \multicolumn{4}{|c|}{ Elongation $(\%)$} & \multicolumn{4}{|c|}{ Reduction of area $(\%)$} \\
\hline & $R T$ & $150^{\circ} \mathrm{C}$ & $180^{\circ} \mathrm{C}$ & $250^{\circ} \mathrm{C}$ & $R T$ & $150^{\circ} \mathrm{C}$ & $180^{\circ} \mathrm{C}$ & $250^{\circ} \mathrm{C}$ & $R T$ & $150^{\circ} \mathrm{C}$ & $180^{\circ} \mathrm{C}$ & $250^{\circ} \mathrm{C}$ & $R T$ & $150^{\circ} \mathrm{C}$ & $180^{\circ} \mathrm{C}$ & $250^{\circ} \mathrm{C}$ \\
\hline 18.8 steel & 20.4 & 15.0 & 14.5 & 13.8 & 58.5 & 47.8 & 46.7 & 46.3 & 74 & 46 & 46 & 42 & 84 & 81 & 81 & 80 \\
\hline $18-13$ Mo steel & 22.2 & 17.8 & 17.5 & 14.8 & 57.9 & 51.0 & 50.1 & 48.3 & 64 & 45 & 43 & 40 & 83 & 80 & 79 & 78 \\
\hline
\end{tabular}

* This paper was presented at the Spring Meeting of the Japan Institute of Metals in April, 1963 and published originally in Japanese in the Journal of the Japan Institute of Metals, 27 (1963), 530.

** Central Research \& Development Laboratory, Kobe Steel Ltd., Kobe, Japan.

(1) R. W. Stachle, F. H. Beck and M. G. Fontana : Corrosion, 15 (1959), $373 \mathrm{t}$. chanical properties of the materials. Forged bars of 15 $\mathrm{mm}$ in diameter and plates of a $5 \times 20 \mathrm{~mm}$ section were heated for $1 \mathrm{hr}$ at $1050^{\circ} \mathrm{C}$, quenched and machined into the direct tension type specimens of $4 \mathrm{~mm}$ in diameter

(2) P.P. Snowden : J. Iron Steel Inst. 186 (1960), 181 ; 187 (1961) 136.

Trans. J I M

1965 Vol. 6 
and the beam specimens of $1.5 \times 15 \times 68 \mathrm{~mm}$, respectively. The specimens were again annealed for $10 \mathrm{~min}$ at $1050^{\circ} \mathrm{C}$ in order to remove the residual stress caused by the machinning, followed by descaling, degreasing and drying.

\section{Stress corrosion cracking tests}

Tests were mainly carried out in 18-8 stainless steel autoclaves with beam specimens and U-bend specimens. The beam specimens were stressed using a titanium jig insulated by a quartz or porcelain bar as shown in Fig. 1. In order to avoid contamination, the tests were carried ed through block $B$ and the sizes of the specimen, with the following expression (Fig. 1) :

$\sigma \max .=3 P l / b h^{2}$

$b$ : width of the specimens, $h:$ thickness of the specimen

However, since the stress-strain curve of material at test temperatures differs from those at room temperature, the true applied stress must be calculated in terms of the strain added to the specimen at room temperature. Therefore, the stress-strain curves at test temperatures as well as at room temperature were measured in advance, and the true stresses at test temperatures were then deter-
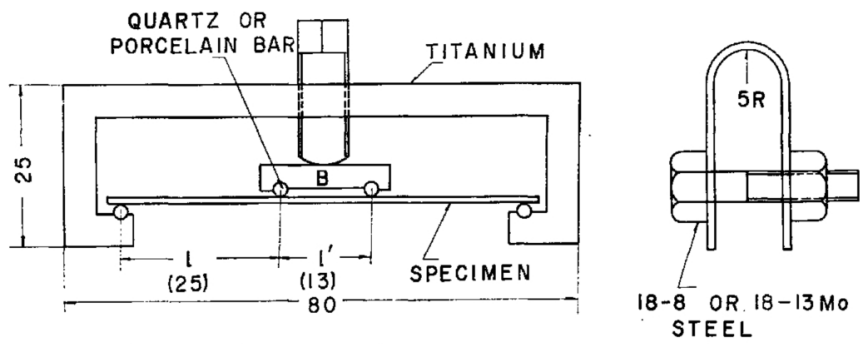

Fig. 1 Stress corrosion specimen and stressing jig.

out in an $1 l$ quartz beaker placed in the autoclave. The beam specimens were placed in the vapor phase in the beaker as well as in the liquid phase with their convex sides facing the center of the beaker, and the U-bend specimens were also placed in both phases with their bending parts being directed upward.

The test solutions were prepared with reagent grade $\mathrm{MgCl}_{2} \cdot 6 \mathrm{H}_{2} \mathrm{O}$ and deionized water, the chloride ion concentrations of which were made $0 \sim 300,000 \mathrm{ppm}$. The chloride ion concentrations in the vapor phase were expressed by those in the liquid phase which was in equilibrium to the vapor phase.

The atmosphere in the autoclave, if not specifically described, was air, but some experiments were performed in the atmosphere of oxygen or argon. Tests were con-

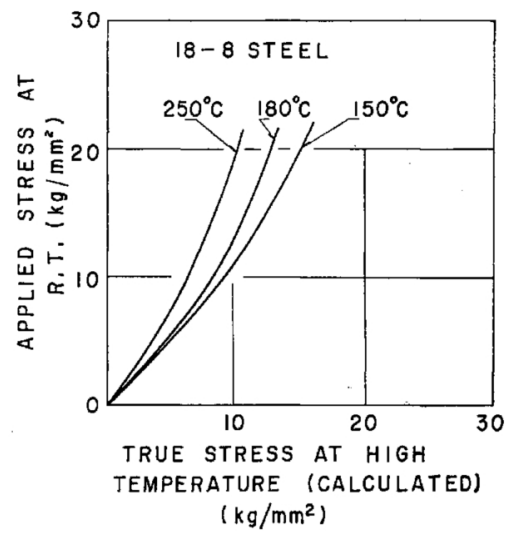

mined as the stress values which corresponded at the temperatures to the strains added to the specimens at room temperature. The relationship between the stress values applied at room temperature and the true stresses at test temperatures is shown in Fig. 2. The values of maximum stresses at room temperature calculated by the above expression were nearly equal to those calculated from the strains which were determined by means of a strain-gauge attached to specimens, at stresses below 20 $\mathrm{kg} / \mathrm{mm}^{2}$. In addition, in order to compare the test results of the beam specimens with those of direct tension type specimens loaded with a constant tension during the test, an experiment was carried out by means of a lever type apparatus (direct tension method) for the stress corrosion cracking of both steels in the boiling $42 \%$

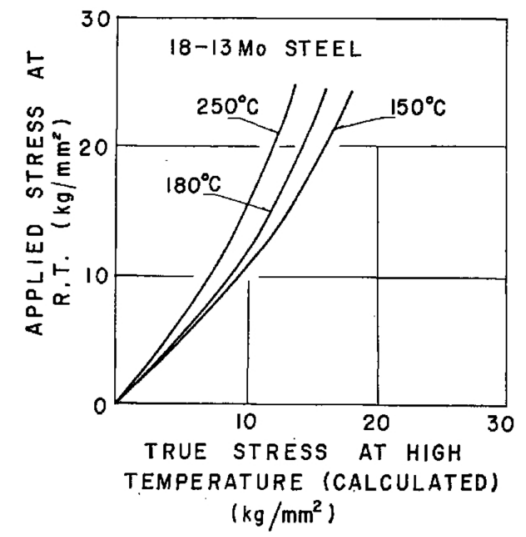

Fig. 2 Calculated stresses at a high temperature of the beam specimen stressed at room temperature.

ducted for the period of $100 \mathrm{hr}$ which was determined in consideration of the relationship between applied stress and time to failure in boiling $42 \% \quad \mathrm{MgCl}_{2}$ under the atmospheric pressure. Cracks on the specimen after tests were inspected by a magnifying glass (magnification : X15).

The maximum stress applied to the beam specimens at room temperature can be calculated from weight $P$ load-
$\mathrm{MgCl}_{2}$.

\section{Experimental Results}

Fig. 3 shows a comparison of test results between the beam method and the direct tension method for the 18-8 steel and the 18-13 $\mathrm{Mo}$ steel in the boiling $42 \% \mathrm{MgCl}_{2}$ solution. The apparent threshold stress obtained by the 
beam method was $13 \sim 14 \mathrm{~kg} / \mathrm{mm}^{2}$ for the $18-8$ steel and $10 \sim 11 \mathrm{~kg} / \mathrm{mm}^{2}$ for the 18-13 Mo steel. Although the direct tension method gave nearly the same curves of applied stress-time to failure as those obtained by the beam method, the apparent threshold stresses obtained to occur at the chloride ion concentration above $30 \mathrm{ppm}$ at $180^{\circ} \mathrm{C}$ and above $10 \mathrm{ppm}$ at $250^{\circ} \mathrm{C}$, whereas no crack were observed in the liquid phase except the solution containing $30,000 \mathrm{ppm}$ chloride ion at $180^{\circ} \mathrm{C}$. Figs. 6 and 7 show the results of the tests at $180^{\circ}$ and $250^{\circ} \mathrm{C}$ when
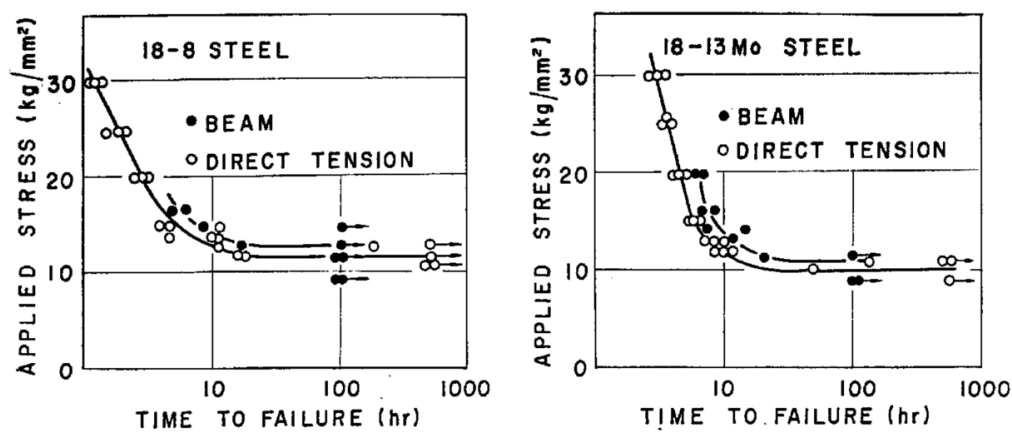

Fig. 3 Results of stress corrosion cracking tests on 18-8 and 18-13 Mo steels in the boilng $42 \% \mathrm{MgCl}_{2}$ solution.

by the former method were $1 \sim 3 \mathrm{~kg} / \mathrm{mm}^{2}$ lower than those of latter in both steels. A possible explanation for the discrepancies would be that the degree of stress relaxation at a test temperature from the stress applied to the beam specimens at room temperature might be larger than the calculated values or the strain would be considerably mitigated after the occurrence of microcracks, and then true stresses loaded on the specimens during the test might further decrease.

In autoclave tests at $130^{\circ}$ and $150^{\circ} \mathrm{C}$, no stress corrosion cracking was observed within $100 \mathrm{hr}$ even the $\mathrm{U}$ bend specimen up to the $30,000 \mathrm{ppm}$ chloride ion concentration. Figs. 4 and 5 show the experimental results

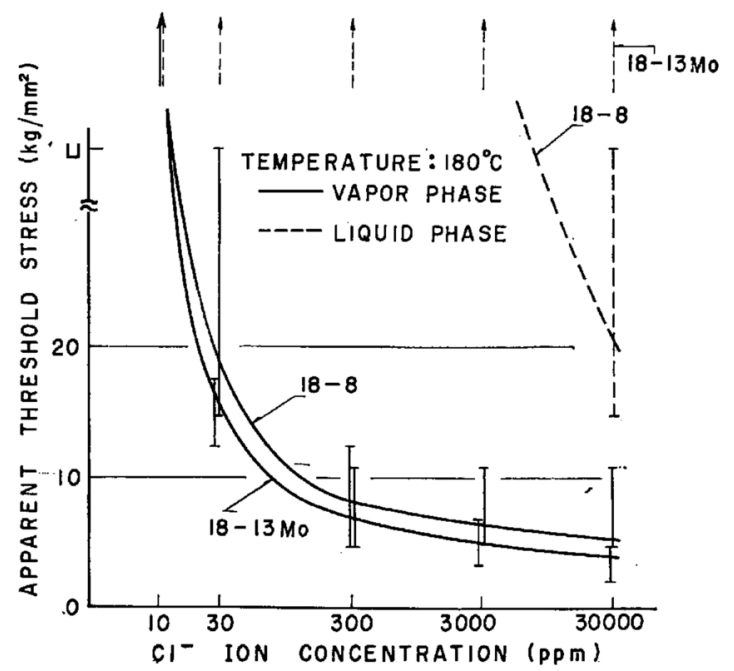

Fig. 4 Relation between $\mathrm{Cl}^{-}$ion concentration and apparent threshold stress in air atmosphere.

(U denotes the stress induced on the $\mathbf{U}$ bend specimen)

at $180^{\circ}$ and $250^{\circ} \mathrm{C}$; the apparent threshold stresses are regarded as the lowest stresses required to cause cracking within $100 \mathrm{hr}$, the values of which are expressed within the range of scattering in the experimental data. The apparent threshold stress generally decreased with increase of the temperature and/or chloride ion concentration, and cracking in the vapor phase occurred at a considerably lower chloride ion concentration than in the liquid phase. In the vapor phase cracks were observed

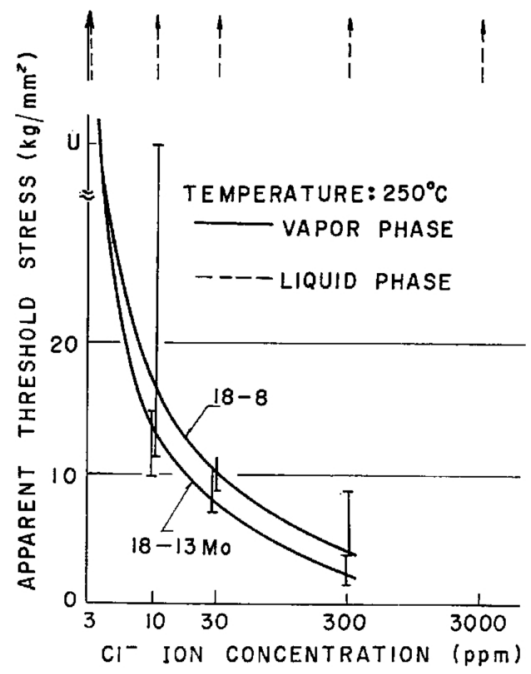

Fig. 5 Relation between $\mathrm{Cl}^{-}$ion concentration and apparent threshold stress in air atmosphere.

( $U$ denotes the stress induced on the $U$ bend specimen)

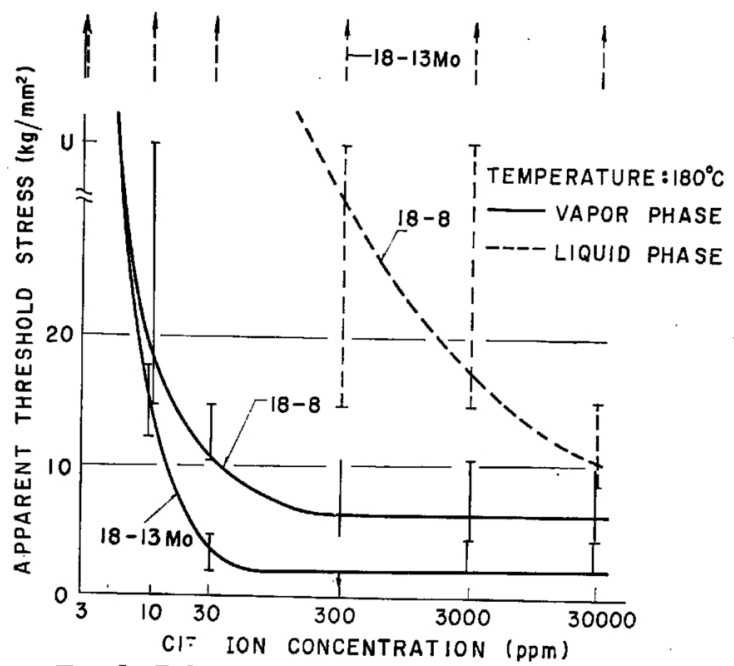

Fig. 6 Relation between $\mathrm{CI}^{-}$ion concentration and apparent threshold stress in oxygen atmosphere.

( $U$ denotes the stress induced on the $U$ bend specimen)

the atmospheres in the autoclave were replaced with oxygen before heating. The presence of oxygen promoted the stress corrosion cracking: in the vapor phase cracks were observed to occur even at the $10 \mathrm{ppm}$ chloride 
ion concentration at $180^{\circ} \mathrm{C}$, where no cracks were found in the case of air atmosphere; in the liquid phase cracks were also observed at the chloride ion concentrations above $300 \mathrm{ppm}$, which were considerably lower than those in air atmosphere. When the atmospheres in the auto-

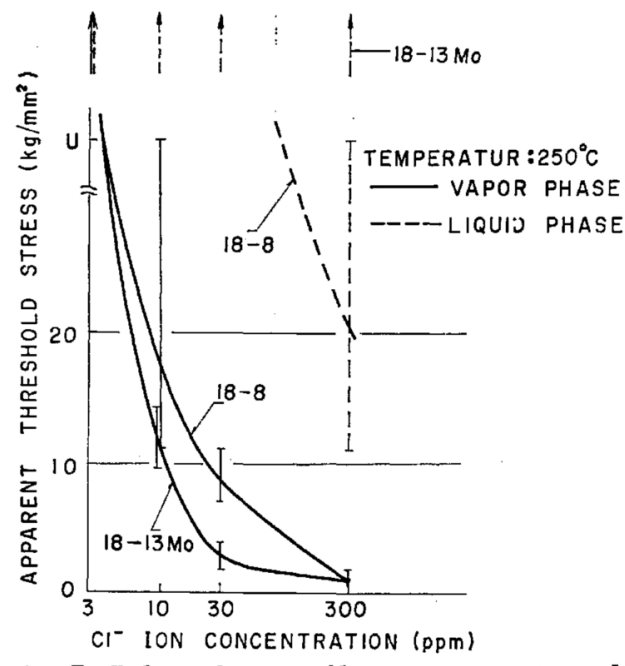

Fig. 7 Relation between $\mathrm{Cl}^{-}$ion concentration and apparent threshold stress in oxygen atmosphere.

( $U$ denotes the stress induced on the $U$ bend specimen)

clave were replaced with argon, neither stress corrosion cracking nor pitting was observed even at the 30,000 ppm chloride ion concentration at $180^{\circ} \mathrm{C}$.

\section{Discussion}

From the above experimental results, the relation between the apparent threshold stress and the temperature or chloride ion concentration in the case of air atmosphere is summarized in Table 3 . The effect of temperature on the stress corrosion cracking was remarkable particularly in the vapor phase, and there seemed to be quite a difference between $150^{\circ}$ and $180^{\circ} \mathrm{C}$ : at the temperature below $150^{\circ} \mathrm{C}$, no cracks were observed up to the $30,000 \mathrm{ppm}$ chloride ion concentration within 100 $\mathrm{hr}$. Since factors affecting stress corrosion cracking, such as chloride ion and oxygen concentration, in the liquid phase would not necessarily be the same as those in the vapor phase, it is not possible to compare directly the experimental results in both phases. However, in general, both steels were more susceptible to stress corrosion cracking in the vapor phase than in the liquid phase. It appears that the tendency to pitting or stress corrosion cracking was increased by succesive condensation and drying of chloride-containing droplets on the specimens which caused a localized concentration of chloride ions. It was observed that all of the cracks both in the vapor phase and in the liquid phase originated from pits, at least in the case of a lower chloride concentration.

The relation between cracks and pits is illustrated in Table 4 ; the number of pits increases with increase of the chloride ion and/or oxygen concentration in the autoclave, along which the tendency to stress corrosion cracking becomes intensified. And the number of pits was larger in the vapor phase in which the tendency to stress corrosion cracking is stronger than in the liquid phase.

In the solutions of a high chloride ion concentration

Table 3 Apparent threshold stresses $\left(\mathrm{kg} / \mathrm{mm}^{2}\right)$ for stress corrosion cracking of $18-8$ and $18-13 \mathrm{Mo}$ steels in chloride solutions in air atmosphere.

\begin{tabular}{|c|c|c|c|c|c|c|c|c|}
\hline & \multirow{2}{*}{$\begin{array}{l}\text { Temperature } \\
\left({ }^{\circ} \mathrm{C}\right)\end{array}$} & \multicolumn{7}{|c|}{$\mathrm{Cl}^{-}$ion concentration (ppm) } \\
\hline & & 3 & 10 & 30 & 300 & 3,000 & 30,000 & 300,000 \\
\hline 130 & $\begin{array}{l}\text { liquid phase } \\
\text { vapor phase }\end{array}$ & 二 & - & $\begin{array}{l}\mathrm{NC} \\
\mathrm{NC}\end{array}$ & $\begin{array}{l}\mathrm{NC} \\
\mathrm{NC}\end{array}$ & $\begin{array}{l}\mathrm{NC} \\
\mathrm{NC}\end{array}$ & $\begin{array}{l}\mathrm{NC} \\
\mathrm{NC}\end{array}$ & 二 \\
\hline 150 & $\begin{array}{l}\text { liquid phase } \\
\text { vapor phase }\end{array}$ & $\overline{-}$ & - & $\begin{array}{l}\text { NC } \\
\text { NC }\end{array}$ & $\begin{array}{l}\mathrm{NC} \\
\mathrm{NC}\end{array}$ & $\begin{array}{l}\mathrm{NC} \\
\mathrm{NC}\end{array}$ & $\begin{array}{l}\mathrm{NC} \\
\mathrm{NC}\end{array}$ & $\begin{array}{c}13 \sim 10 \\
-\end{array}$ \\
\hline 180 & $\begin{array}{l}\text { liquid phase } \\
\text { vapor phase }\end{array}$ & 二 & $\begin{array}{l}\mathrm{NC} \\
\mathrm{NC}\end{array}$ & $\underset{\mathrm{U} \sim 12}{\mathrm{NC}}$ & $\stackrel{\mathrm{NC}}{12 \sim 5}$ & $\underset{10 \sim 2}{\mathrm{NC}}$ & $\begin{array}{l}\mathrm{U} \sim 15 \\
10 \sim 2\end{array}$ & 二 \\
\hline 250 & $\begin{array}{l}\text { liquid phase } \\
\text { vapor phase }\end{array}$ & $\begin{array}{l}\text { NC. } \\
\text { NC }\end{array}$ & $\underset{\mathbf{U} \sim 10}{\mathrm{NG}}$ & $\stackrel{\mathrm{NC}}{11 \sim 8}$ & $\begin{array}{c}\mathrm{NC} \\
9 \sim 2\end{array}$ & NG & $\begin{array}{l}\text { GC } \\
\text { GC }\end{array}$ & - \\
\hline
\end{tabular}

NC : no crack ; GC : general corrosion; $U$ : stress induced on the $U$ bend specimen.

Table 4 Numbers of pits after $100 \mathrm{hr}$ tests at $250^{\circ} \mathrm{C}\left(\mathrm{pits} / \mathrm{cm}^{2}\right)$.

\begin{tabular}{|c|c|c|c|c|c|c|c|c|c|}
\hline \multirow{3}{*}{ Materials } & \multirow{3}{*}{$\begin{array}{l}\text { Applied } \\
\text { stress } \\
\left(\mathbf{k g} / \mathrm{mm}^{2}\right)\end{array}$} & \multicolumn{4}{|c|}{$\mathrm{Cl}^{-1} 10 \mathrm{ppm}$} & \multicolumn{4}{|c|}{$\mathrm{Cl}^{-} 300 \mathrm{ppm}$} \\
\hline & & \multicolumn{2}{|c|}{ Air } & \multicolumn{2}{|c|}{ Oxygen } & \multicolumn{2}{|c|}{ Air } & \multicolumn{2}{|c|}{ Oxygen } \\
\hline & & Liquid & Vapor & Liquid & Vapor & Liquid & Vapor & Liquid & Vapor \\
\hline $\begin{array}{l}18 \_8 \\
\text { steel }\end{array}$ & $\begin{array}{c}\text { U bend } \\
11 \\
8.7 \\
3.6 \\
1.5\end{array}$ & $\begin{array}{l}0 \\
0 \\
0 \\
- \\
-\end{array}$ & $\begin{array}{l}0 \\
0 \\
0 \\
- \\
-\end{array}$ & $\begin{array}{l}0 \\
0 \\
0 \\
- \\
-\end{array}$ & $\begin{array}{c}10^{*} \\
7 \\
4 \\
- \\
-\end{array}$ & $\begin{array}{r}8 \\
10 \\
10 \\
- \\
-\end{array}$ & $\begin{array}{l}8^{*} \\
8^{*} \\
8^{*} \\
3 \\
-\end{array}$ & $\begin{array}{l}7^{*} \\
15 \\
15 \\
-\end{array}$ & $\begin{array}{l}2_{2 *} \\
2_{2 *} \\
2^{*} \\
2^{*} 0^{*} \\
>20^{*}\end{array}$ \\
\hline $\begin{array}{l}\text { 18_13 Mo } \\
\text { steel }\end{array}$ & $\begin{array}{c}\text { U bend } \\
14 \\
9.5 \\
3.6 \\
1.5\end{array}$ & $\begin{array}{l}0 \\
0 \\
0 \\
- \\
-\end{array}$ & $\begin{array}{l}0 \\
0 \\
0 \\
-\end{array}$ & $\begin{array}{l}0 \\
0 \\
0 \\
- \\
-\end{array}$ & $\begin{array}{c}10^{*} \\
1^{*} \\
1 \\
= \\
-\end{array}$ & $\begin{array}{l}3 \\
6 \\
6 \\
- \\
-\end{array}$ & $\begin{array}{l}8^{*} \\
8^{*} \\
8^{*} \\
5^{*} \\
0\end{array}$ & $\begin{array}{l}0 \\
0 \\
2 \\
0 \\
-\end{array}$ & $\begin{array}{l}2_{2 *}^{*} \\
2^{*} \\
2^{*} \\
2^{*} 0^{*} \\
2_{2 *}^{*}\end{array}$ \\
\hline
\end{tabular}


such as boiling $42 \% \mathrm{MgCl}_{2}$ solution, the susceptibility to stress corrosion cracking of the 18-8 steel was almost the same as the 18-13 Mo steel. However, in the solutions of a low chloride ion concentration the 18-8 steel exhibited a higher resistance to stress corrosion cracking than the 18-13 Mo steel in the vapor phase and a lower resistance in the liquid phase. The difference in crack susceptibility of both steels by the environments was probably due to the difference in the stability of surface films and the shape of pits on each steel which resulted in different degrees of the stress concentration. That is, since the 18-13 Mo steel is less susceptible to pitting corrosion than the 18-8 steel in mild corrosives such as solutions of low chloride ion concentrations, it is more resistant to cracking that originates from pits. However, at high chloride ion concentrations in the liquid phase, or even at low chloride ion concentrations in the vapor phase, where the conditions to cause pitting corrosion are severe, the 18-13 Mo steel also suffers from pitting corrosion. In these cases the shape of pits is considered to play an important role in the stress concentration.

Table 5 shows an example of measurements of pit

Table 5 Size and shape of pits after 100 -hr tests with the chloride concentration of 30 ppm in oxygen atmosphere at $250^{\circ} \mathrm{C}$.

\begin{tabular}{|c|c|c|c|c|c|}
\hline Materials & $\begin{array}{c}\text { Applied } \\
\text { stress } \\
\left(\mathrm{kg} / \mathrm{mm}^{2}\right)\end{array}$ & Phase & $\begin{array}{r}\text { Depth } \\
(\mathrm{mm})\end{array}$ & $\begin{array}{l}\text { Diameter } \\
\quad(\mathrm{mm})\end{array}$ & $\begin{array}{l}\text { Depth/ } \\
\text { diameter }\end{array}$ \\
\hline $\begin{array}{l}18-8 \\
\text { steel }\end{array}$ & $\begin{array}{l}11 \\
8.7 \\
11 \\
8.7\end{array}$ & $\begin{array}{l}\text { liquid } \\
\text { liquid } \\
\text { vapor } \\
\text { vapor }\end{array}$ & $\begin{array}{c}0.025 \\
0.028 \\
\overline{0.050}\end{array}$ & $\begin{array}{c}0.050 \\
0.043 \\
\overline{0.073}\end{array}$ & $\begin{array}{l}0.50 \\
0.68 \\
\overline{0.76}\end{array}$ \\
\hline $\begin{array}{l}18-13 \mathrm{Mo} \\
\text { steel }\end{array}$ & $\begin{array}{c}14 \\
9.5 \\
14 \\
9.5\end{array}$ & $\begin{array}{l}\text { liquid } \\
\text { liquid } \\
\text { vapor } \\
\text { vapor }\end{array}$ & $\begin{array}{l}\overline{ } \\
0.095 \\
0.065\end{array}$ & $\begin{array}{l}\overline{ } \\
0.035 \\
0.035\end{array}$ & $\begin{array}{l}\overline{ } \\
2.5 \\
1.9\end{array}$ \\
\hline
\end{tabular}

geometry which was observed by a microscope on sections of the specimens tested. The 18-13 Mo steel was observed to be larger in depth/radius ratios of the pits than the 18-8 steel, with larger degrees of stress concentration which coincide with the stress corrosion cracking behavior. Calculation of the stress concentration coefficients from the data of Table 5 using Keating's expres$\operatorname{sion}^{(3)}, 1+2(h / r)^{1 / 2}$, gives a maximum value of 5 . The experimental results by Fontana(1) on $18-8 \mathrm{Cb}$ steel at $200^{\circ} \mathrm{C}$ show that the occurrence of stress corrosion cracking is independent of applied stress, whereas the present results clearly show a pronounced effect of stress as shown in Figs. 4 and 5.

In general, it may reasonably be considered that the occurrence of stress corrosion cracking depends on applied stress, but the stress dependence may diminish if the degree of stress concentration caused by pits become much greater.

(3) F.H. Keating: "Chemical manifestations of internal stress" in symposium on internal stress in metals and alloys. The Institute of Metals (1958).
The increase of susceptibility to stress corrosion cracking with increase of the oxygen concentration in atmosphere and the complete elimination of cracking by exclusion of oxygen by argon indicate that oxygen plays an important role in the stress corrosion cracking behavior in the neutral chloride solution of a low concentration. However, it has been reported that even in the absence of oxygen cracking would occur in the $42 \%$ $\mathrm{MgCl}_{2}{ }^{(4)}$ solution of a high chloride ion concentration. Therefore, it is considered that the role of oxygen has a bearing on the formation of pits as a preliminary stage of stress corrosion cracking. Streicher ${ }^{(5)}$ reported that the presence of an oxidizing agent was required to cause a pitting corrosion of stainless steels in a neutral chloride solution. In the course of pit formation the cathodic reaction such as $\mathrm{O}_{2}+2 \mathrm{H}_{2} \mathrm{O}+4 \mathrm{e} \rightarrow 4 \mathrm{OH}^{-}$must proceed at an adequate speed in the cathodic area. However, in the course of crack propagation, the diffusion of oxygen into the gaps of cracks becomes difficult and the hydrogen ion concentration can be raised in the gap through an anodic reaction or a hydrolysis reaction of metallic chloride. The $\mathrm{H}++\mathrm{e} \rightarrow 1 / 2 \mathrm{H}_{2}$ reaction will take place predominantly as the cathodic reaction, and therefore the presence of oxygen becomes unnecessary.

\section{Conclusion}

(1) Susceptibility to stress corrosion cracking was found to increase with increase of the chloride ion concentration and/or temperature. At temperatures below $150^{\circ} \mathrm{C}$, no stress corrosion cracking was observed except in the boiling $42 \% \mathrm{MgCl}_{2}$ solution. In the vapor phase cracks were found above the $30 \mathrm{ppm}$ chloride ion concentration at $180^{\circ} \mathrm{C}$ and above $10 \mathrm{ppm}$ at $250^{\circ} \mathrm{C}$, while in the liquid phase only the $18-8$ steel cracked at the $30,000 \mathrm{ppm}$ chloride ion concentration at $180^{\circ} \mathrm{C}$.

(2) The susceptibility was generally increased by replacing the atmosphere in the autoclave with oxygen; cracks were found in the vapor phase above the $10 \mathrm{ppm}$ chloride ion concentration at $180^{\circ} \mathrm{C}$ and $250^{\circ} \mathrm{C}$, while in the liquid phase only the $18-8$ steel cracked above the $300 \mathrm{ppm}$ chloride ion concentration at $180^{\circ} \mathrm{C}$.

(3) The 18-13 Mo steel was observed to be more susceptible to cracking than the $18-8$ steel in the vapor phase in a dilute chloride solution and less susceptible in the liquid phase.

(4) These results suggested the existence of difinite threshold stresses for stress corrosion cracking which depended on the chemical composition of material and the corrosivity of environments such as temperature, chloride and oxygen concentrations.

(5) It was observed that all cracks in dilute chloride solutions originated from pits and a complete exclusion of oxygen eliminated the occurrence of stress corrosion cracking as well as pitting corrosion.

(4) H. H. Uhlig and J. Lincoln : J. Electrochem. Soc., 105(1958), 325.

(5) M. A. Streicher : J. Electrochem. Soc., 103 (1956), 375. 